\title{
SEASONAL CHANGES IN BROOD SEX COMPOSITION IN AUDOUIN'S GULLS
}

Author(s): Meritxell Genovart, Daniel Oro , Xavier Ruiz, Richard Griffiths, Pat Monaghan, and Ruedi G. Nager

Source: The Condor, 105(4):783-790. 2003.

Published By: Cooper Ornithological Society

DOI: http://dx.doi.org/10.1650/7265

URL: http://www.bioone.org/doi/full/10.1650/7265

BioOne (www.bioone.org) is a nonprofit, online aggregation of core research in the biological, ecological, and environmental sciences. BioOne provides a sustainable online platform for over 170 journals and books published by nonprofit societies, associations, museums, institutions, and presses.

Your use of this PDF, the BioOne Web site, and all posted and associated content indicates your acceptance of BioOne's Terms of Use, available at www.bioone.org/page/terms_of_use.

Usage of BioOne content is strictly limited to personal, educational, and non-commercial use. Commercial inquiries or rights and permissions requests should be directed to the individual publisher as copyright holder. 


\title{
SEASONAL CHANGES IN BROOD SEX COMPOSITION IN AUDOUIN'S GULLS
}

\author{
Meritxell Genovart ${ }^{1,2,3,4}$, Daniel Oro ${ }^{1}$, Xavier Ruiz ${ }^{2}$, Richard GriffithS ${ }^{3}$, \\ Pat Monaghan ${ }^{3}$ AND Ruedi G. NAGER ${ }^{3}$ \\ Institut Mediterrani d'Estudis Avançats (CSIC-UIB), Miquel Marquès 21, 07190 Esporles, Mallorca, Spain \\ ${ }^{2}$ Dept. Biologia Animal, Vertebrats, Universitat de Barcelona, Avgda. Diagonal 645, 08028 Barcelona, Spain \\ ${ }^{3}$ Division of Environmental and Evolutionary Biology, Institute of Biomedical and Life Sciences,
} Graham Kerr Building, University of Glasgow, G12 8QQ, UK

\begin{abstract}
We examined seasonal variation in the hatching sex ratio of Audouin's Gull (Larus audouinii). This species is sexually size dimorphic (males are $20 \%$ larger than females at fledging); it has a modal clutch of three eggs, which vary in size (the third egg is the smallest) and hatch asynchronously. These sex, egg size, and hatching patterns generate substantial within-brood differences in chick size that interact with the food provisioning of the parents to influence chick survival. Parental provisioning capacity depends on both parental quality and environmental conditions, both of which are known to decline with season. Consequently, the optimal brood composition is likely to vary within a season. Using molecular markers to sex newly hatched chicks, we found that offspring sex was influenced by an interaction between hatching date and hatching order, with the proportion of males among third-hatched chicks initially increasing and then decreasing later in the season.
\end{abstract}

Key words: Audouin's Gull, food availability, Larus audouinii, seasonal change, sex ratio.

Cambios Estacionales en la Proporción de Sexos de las Polladas en Larus audouinii

\begin{abstract}
Resumen. En el presente trabajo examinamos la variación estacional en la proporción de sexos de los pollos de Larus audouinii en el momento de la eclosión. Esta especie es sexualmente dimórfica (los machos son un 20\% mayores que las hembras al acabar su crecimiento), tiene una puesta modal de tres huevos, que varían en tamaño (el tercero es el menor) y eclosionan asincrónicamente. Estos patrones de sexo, tamaño del huevo y orden de eclosión generan diferencias sustanciales en el tamaño de los pollos dentro de la pollada, los que a su vez interaccionan con la provisión de alimento de los progenitores influyendo la supervivencia de cada pollo. La capacidad de proveer alimento dependerá de la calidad parental y de las condiciones ambientales, las cuales suelen disminuir a lo largo de la estación reproductora. En consecuencia, la composición óptima de la pollada probablemente varía en cada estación. Una vez identificado de sexo de los pollos mediante técnicas moleculares, encontramos que el sexo de la progenie estuvo influenciado por la interacción entre la fecha de eclosión y el orden de eclosión, de modo que la proporción de machos en los huevos eclosionados en tercer lugar incrementó inicialmente y luego disminuyó al final de la estación.
\end{abstract}

\section{INTRODUCTION}

Sex allocation theory predicts that when circumstances alter the fitness value of male and female offspring, parents should manipulate the sex of their progeny to obtain the maximum fitness benefits from a given breeding attempt (Trivers and Willard 1973, Frank 1990, Gowaty 1991). When resources are in short supply, and one offspring sex is more vulnerable to such shortage, the reproductive value of the sexes could differ

Manuscript received 16 December 2002; accepted 13 May 2003.

${ }^{4}$ E-mail: m.genovart@uib.es and it should be more profitable for parents to produce the less vulnerable sex. A number of studies on birds have demonstrated that offspring sex ratios can differ from equality (Burley 1981, Ellegren et al. 1996, Nager et al. 1999). Such sex ratio biases may be the consequence of rearing conditions that differently affect the survival of female and male offspring (CluttonBrock et al. 1985, Weatherhead and Teather 1991, Post et al. 1999) or of biases in the actual production of the two sexes; the proximate mechanisms underlying such offspring sex-ratio biases remain unclear (Krackow 1995, Emlen 1997, Sheldon 1998). 
In addition to effects attributable to the sex of the offspring itself, offspring survival may also depend on the sex of siblings. Within broods, differences in offspring size or age caused by variation in egg size and hatching asynchrony produce competitive feeding hierarchies that disadvantage the smaller or later-hatched chicks (Stenning 1996). In sexually size-dimorphic species with hatching asynchrony, success in competing with siblings may also be affected by differences in growth between the sexes (Lack 1954, Mock and Parker 1997). Therefore, some sex compositions within broods might result in higher nesting success than others (Bortolotti 1986, Drummond et al. 1991, Nager et al. 2000). Optimal brood composition may therefore vary within years in relation to seasonal changes in the environment or the phenotypes of breeders. Several avian studies have previously found seasonal variation in brood sex ratios (Daan et al. 1996, Lessells et al. 1996, Tella et al. 1996, but see Verboven et al. 2002). However little is known about whether these sex biases equally affect all chicks within a brood (Wiebe and Bortolotti 1992, Velando et al. 2002). For example, in gulls last-hatched chicks are more vulnerable under poor conditions (Parsons 1975, Hébert and Barclay 1988, Oro et al. 1996), and this trend is more marked for males than for females (Griffiths 1992, Nager et al. 1999, 2000).

We examined sex ratio at hatching in broods of Audouin's Gull (Larus audouinii) at the Ebro Delta, Spain, in relation to the hatching order and hatching date of chicks. As in other larids, Audouin's Gulls usually lay a clutch of three eggs that hatch asynchronously (Oro 1998). At fledging males are 20\% larger than females (Oro 1998), and as chicks they are more vulnerable to food shortage (Ruiz et al. 1998, Genovart et al. 2003). Several studies on gulls have demonstrated that birds of poorer quality breed later in the season (Parsons 1975, Hunt and Hunt 1976, Brouwer et al. 1995) and lay smaller eggs (Bolton 1991). Parents in poor condition may therefore struggle to raise the more expensive sex (males in this case) and might benefit by avoiding male offspring in the last hatching position (Meathrel and Ryder 1987, Nager et al. 1999). Thus we expected that offspring sex distributions within broods would differ between birds laying early and late in the season, with a female bias appearing in third eggs laid late in the season in particular.

\section{METHODS}

Data were collected during 1998 in the protected area of the Punta de la Banya (Ebro Delta, Catalonia, Spain, $\left.40^{\circ} 37^{\prime} \mathrm{N}, 00^{\circ} 35^{\prime} \mathrm{E}\right)$, a flat and sandy peninsula. Here, ca. 11700 pairs of Audouin's Gulls bred in 1998, approximately $65 \%$ of the total world breeding population.

In the first two weeks of May, during the incubation period, we selected 51 nests containing three-egg clutches, dispersed throughout the breeding colony. Three is the modal clutch size (ca. 70\% of the nests, Oro 1998), and we selected only three-egg clutches in order to control for the level of intrabrood competition between siblings. Before hatching, all the eggs were measured (maximum length and width) with digital calipers to the nearest $0.1 \mathrm{~mm}$, and marked with waterproof ink for identification. We calculated egg volume $($ in $\mathrm{mL}$ ) as $\mathrm{V}=0.000485 \times$ egg length $\times$ (egg width $)^{2}$ following Oro et al. (1996). Egg volume reflects food availability during the prelaying period $\left(r^{2}=0.89\right.$, Oro et al. 1999; see also Oro et al. 1996, Oro 1999) and we therefore used egg volume as a reliable indicator of the feeding conditions during laying in the study year. Because eggs within a clutch are not statistically independent, we calculated the mean egg volume for each clutch and conducted analyses by clutches. All selected nests were then enclosed with a wire net $1 \mathrm{~m}$ high and $3 \mathrm{~m}$ in diameter to prevent chicks from moving away from the nest site once they hatched.

From the expected hatching time onward we checked the nests every day to record hatching dates, hatching order, and the egg from which each chick hatched. We recorded the hatching order of 133 chicks (in three cases two chicks had already hatched at the first visit). Hatching asynchrony averaged $0.8 \pm 0.1$ days $(\mathrm{SD} ; n=$ 48) between the first and the second chick and $1.3 \pm 0.1(n=36)$ days between the second and the third chick. On the day of hatching, new chicks were marked and a small blood sample (ca. $50 \mu \mathrm{L}$ ) was taken from the leg vein. No ill effects of taking a blood sample from chicks were observed. We collected blood in a capillary tube and transferred it into a tube with an approximately equal volume of preservative buffer containing $50 \mathrm{mM}$ EDTA, 2\% SDS and $50 \mathrm{mM}$ Tris pH 8 (Griffiths et al. 1992). Samples were stored for several weeks at room temperature before analysis. DNA was extracted using the phe- 
nol/chloroform method, following digestion with proteinase K (Sambrook et al. 1989). We sexed the chicks using the polymerase chain reaction to amplify two CHD genes (Griffiths et al. 1996, 1998), scoring one band in males and two bands in females. We increased the annealing temperature to $52^{\circ} \mathrm{C}$ to get a better amplification in this species. Results were observed on a 3\% agarose gel stained with ethidium bromide.

During the chick-rearing stage, we visited nests only every five days, to reduce disturbance, until all chicks had either died or fledged. We did not test for differential nestling mortality of male and female offspring because only three of the chicks survived to the fledging period in our study nests. An important food source for Audouin's Gulls breeding at the Ebro Delta is the fish discarded by trawlers, and in the study year the establishment of a trawling moratorium in the middle of the chick-rearing stage sharply decreased food availability (Ruiz et al. 1998) and caused low breeding success in the entire colony (Genovart et al., unpubl. data).

\section{STATISTICAL ANALYSES}

We analyzed egg volume in relation to year and laying date. In order to evaluate the conditions during egg production, mean egg volume of clutches in the study year was compared with data previously recorded at the same colony (1992-1997) using ANOVA, with Tukey's HSD post hoc tests. We also tested for a relationship between egg volume and hatching date, by dividing the spread of hatching dates into three periods: early (first 5 days of the hatching period), middle (days 6-9) and late (days 10-15), and then compared mean egg volume among time periods using ANOVA with Tukey's HSD post hoc tests.

We used a generalized linear model with binomial error distributions and logit as the link function to analyze the relationship between offspring sex and hatching order, egg volume, hatching date, and hatching success. To take into account the nonindependence of chicks in a brood, we included a random effect of female in the logistic regression model. We also tested for interactions between independent factors, but dropped them when nonsignificant. To test for nonlinear effects of hatching date on offspring sex, we also included hatching date as a quadratic function. The Hosmer and Lemeshow (1989) test was used to assess the goodness of
TABLE 1. Mean $\pm \mathrm{SD}$ egg volume (in $\mathrm{mL}$ ) in threeegg clutches of Audouin's Gull breeding at the Ebro Delta, Spain, during 1992 to 1998. An important food source in this population is fish discarded by trawlers, and differences in trawling activity are reflected in egg volumes (Oro et al. 1999). The sample size is the number of clutches analyzed.

\begin{tabular}{cccr}
\hline \hline Year & $\begin{array}{c}\text { Trawling } \\
\text { activity }\end{array}$ & $\begin{array}{c}\text { Egg volume } \\
(\text { mean } \pm \text { SD) }\end{array}$ & \multicolumn{1}{c}{$n$} \\
\hline 1992 & No & $57.3 \pm 2.8$ & 20 \\
1993 & Yes & $60.4 \pm 3.2$ & 66 \\
1994 & Yes & $60.3 \pm 3.7$ & 126 \\
1995 & Yes & $60.8 \pm 3.2$ & 91 \\
1996 & Yes & $58.3 \pm 3.7$ & 26 \\
1997 & Yes & $59.1 \pm 2.9$ & 68 \\
1998 & Yes & $59.9 \pm 3.5$ & 51 \\
\hline
\end{tabular}

fit of the model. Only models that passed this test $(P>0.5)$ were accepted for further analysis. The significance of the main effects and interactions were assessed by comparing models with or without the effects tested. A model including two factors and their interaction was described using an asterisk. Additive models were described using a "+" symbol instead. For instance, the model (sex order*hatching date) designated a model where offspring sex varied with hatching order and hatching date, with the effect of order potentially different at different hatching dates. Selection of the model was made on the basis of Akaike's Information Criterion $\left(\mathrm{AIC}_{c}\right)$ adjusted for small sample sizes; the model with the smallest $\mathrm{AIC}_{c}$ was selected as the most parsimonious (Burnham et al. 1994, 1995). Models with a difference of $\leq 2$ in $\mathrm{AIC}_{c}$ values were considered to be statistically equivalent (Anderson et al. 1994). All models including random effects were fitted using EGRET software (version 2.0.3, Cytel Software Corporation 1990), which automatically scaled the deviances according to the estimated overdispersion. Throughout the text, means \pm SE are reported.

\section{RESULTS}

Mean egg volume in 1998 was $59.9 \pm 3.5 \mathrm{~mL}$ $(n=51)$. Significant differences among years were found in the average egg volume of threeegg clutches $\left(F_{6,447}=5.2, P<0.001\right.$; Table 1$)$. The year without trawling activity during the laying period (1992) was the only one with significantly smaller clutches (Tukey's HSD, $P<$ $0.05)$. There was a tendency for egg size to decrease with laying date. When hatching dates 


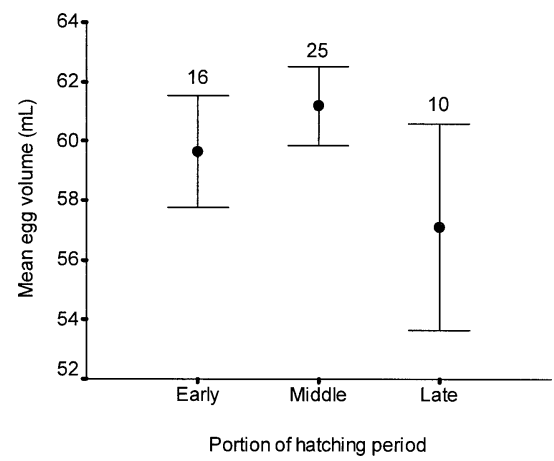

FIGURE 1. Mean $\pm 95 \% \mathrm{CI}$ egg volume in Audouin's Gulls breeding at Ebro Delta, Spain, in relation to hatching date. Mean volumes are plotted for early (day 1-5), middle (day 6-9) and late (day 10-15) hatching period, depending on the date of hatching of the first egg. All clutches analyzed contained three eggs. Numbers above bars are sample sizes (clutches).

were plotted in the three periods defined in the methods, we found a significant difference in mean egg volume mainly between middle and late clutches $\left(F_{2,48}=4.5, P<0.02\right.$; Tukey's HSD, $P<0.02$; Fig. 1).

Hatching success was high $(91 \pm 2 \%, n=$ 153). Fourteen of the 51 nests failed to hatch one egg each; of these five contained a dead embryo and the rest showed no signs of development, which could have been due to infertility or early embryo mortality. We took blood samples of all 139 chicks. Nine samples were lost in transit, and the remaining 130 were sexed successfully.

We did not find a significant difference in offspring sex ratios among females (likelihood ratio $<0.001$, df $=1, P=0.50$ ). The constant of the model that included only the female random effect differed significantly from 0 (constant $=$ $0.37 \pm 0.12 ; P<0.04)$ indicating that the proportion of male offspring was larger than $50 \%$. The model that best fitted our data on offspring sex (with the lowest $\mathrm{AIC}_{c}$ value) included hatching order, the quadratic function of the hatching date and their interaction (Table 2). Offspring sex was not related to egg size, nor was there any relationship between offspring sex and hatching success (Table 2).

Offspring sex was nonrandomly allocated with respect to hatching order and hatching date. The seasonal change in offspring sex for each hatching position (first to third) is shown in Figure 2 . The probability of first-hatched chicks being male was above 0.50 throughout the observation period and increased with hatching date. Among second-hatched, and more clearly among third-hatched chicks, there was a peak in the probability of chicks being male in the middle period; nearly all third-hatched chicks of early and late breeders were female.

\section{DISCUSSION}

Several studies on sexually size-dimorphic birds with hatching asynchrony, such as some raptors

TABLE 2. Analysis of the relationship between offspring sex and hatching order, egg volume, hatching date, and hatching success of siblings. Model selection used Akaike's Information Criterion adjusted for small sample sizes $\left(\mathrm{AIC}_{c}\right)$. The lowest $\mathrm{AIC}_{c}$ score indicates the best-approximating model. $\Delta \mathrm{AIC}_{c}$ is the difference in $\mathrm{AIC}_{c}$ between a given model and the best-approximating model. The $\mathrm{AIC}_{c}$ weight indicates the support for each model relative to other models, and sums to 1 (Burnham and Anderson 1998). $k$ is the number of parameters. All the models except the null model also included the female random effect.

\begin{tabular}{|c|c|c|c|c|c|}
\hline Model & Deviance & $k$ & $\mathrm{AIC}_{c}$ & $\Delta \mathrm{AIC}_{c}$ & $\begin{array}{c}\mathrm{AIC}_{c} \\
\text { weight }\end{array}$ \\
\hline Null & 146.21 & & & & \\
\hline Order $\times(\text { Hatching date })^{2}$ & 122.73 & 10 & 144.93 & 0 & 0.66 \\
\hline Order $+(\text { Hatching date })^{2}$ & 135.33 & 6 & 148.14 & 3.21 & 0.13 \\
\hline Order $\times$ Hatching date $+(\text { Hatching date })^{2}$ & 132.24 & 8 & 149.65 & 4.72 & 0.06 \\
\hline Order $\times$ Hatching date & 135.58 & 7 & 150.67 & 5.74 & 0.04 \\
\hline Hatching success & 143.69 & 3 & 149.91 & 4.98 & 0.05 \\
\hline Hatching date & 146.21 & 3 & 152.43 & 7.50 & 0.02 \\
\hline Volume & 145.89 & 3 & 152.11 & 7.18 & 0.02 \\
\hline Order & 145.60 & 4 & 153.98 & 9.05 & 0.01 \\
\hline Order + Hatching date & 144.02 & 5 & 154.59 & 9.66 & 0.00 \\
\hline Order + Volume & 143.80 & 5 & 154.37 & 9.44 & 0.01 \\
\hline Order $\times$ Volume & 143.12 & 7 & 158.21 & 13.28 & 0.00 \\
\hline Order + Hatching success + Hatching date & 141.10 & 6 & 153.91 & 8.98 & 0.01 \\
\hline
\end{tabular}




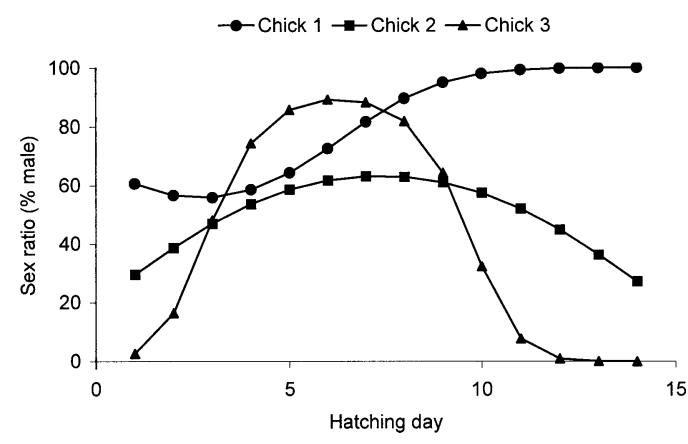

FIGURE 2. Changes in offspring sex ratio (proportion of males) in Audouin's Gulls breeding at the Ebro Delta, Spain, in relation to hatching date and hatching order, derived from estimates of the best-approximating model (see Table 2). Hatching day 0 corresponds to 21 May 1998.

and seabirds, have reported adjustments in brood sex ratios under situations of high or low food supply (Wiebe and Bortolotti 1992, Dzus et al. 1996, Appleby et al. 1997, Nager et al. 1999, Torres and Drummond 1999, Kalmbach et al. 2001, but see Tella et al. 1996). Our proportion of male offspring at hatching was larger than $50 \%$, and our egg volume data show that during the prelaying period of 1998 food was not scarce, since the 1998 egg volume was similar to that in other years when trawlers were active in the area (Oro et al. 1996, Oro 1998).

We found significant changes in brood sex composition with season in Audouin's Gulls. The probability of eggs being male was greater than 0.5 throughout the season in first eggs, and increased with hatching date. Second and third eggs were more likely to be female in the early and late parts of the season, but tended to be male biased in the middle period. Variation in offspring sex ratio in relation to laying order has been found in Red-winged Blackbirds (Agelaius phoeniceus; Weatherhead 1983), Bald Eagles (Haliaeetus leucocephalus; Dzus et al. 1996), Montagu's Harriers (Circus pygargus; Leroux and Bretagnolle 1996), and House Finches (Carpodacus mexicanus; Badyaev and Hill 2000). The evidence for changes in offspring sex ratio with hatching order in unmanipulated gull nests is, however, controversial. Ryder (1983) found a significant female bias in the last-laid egg of Ring-billed Gulls (L. delawarensis), but this was not confirmed by later studies on gulls (Ryder and Termaat 1987, Sayce and Hunt 1987, Griffiths 1992, Bradbury and Griffiths 1999). Since our data relate to hatching sex ratios, the bias at hatching could have resulted from a sex bias at laying, or from differential embryo mortality as found in Tree Swallows (Tachycineta bicolor, Whittingham and Dunn 2001, but see Nager et al. 1999). The differences among studies may have been due to differences in food availability, and the bias toward females in last-hatched chicks might only occur when little food is available (Meathrel and Ryder 1987, Nager et al. 1999).

In this study we only used three-egg clutches, and consequently our results only relate to birds laying clutches of this size. An alternative strategy to optimize brood fitness may be to lay only two or even one egg later in the season; the optimal brood sex composition may be different for birds laying fewer than three eggs. Further studies studying sex-ratio simultaneously in smaller clutches would help to evaluate this possibility.

A few other studies have shown that the distribution of sexes in relation to laying or hatching order varies through the breeding season. However, the patterns differ between species: Velando et al. (2002) concluded from their study on Shags (Phalacrocorax aristotelis) that the sex ratio of only first-hatched chicks changed through the season. In American Kestrels (Falco sparverius), however, only the sex ratio of the youngest chick changed through the season, from females early in the season to males later in the season (Wiebe and Bortolotti 1992). Similarly, in Audouin's Gulls in this study, the most marked seasonal change in the bias of offspring sex ratio occurred among the later-hatched chicks. The probability of first-hatching eggs being male was high throughout the study period, whereas early and particularly late breeders produced more female second- and third-hatched chicks. In contrast, in the European Kestrel ( $F$. tinnunculus) offspring sex ratio varied both in first- and last-hatched young (Dijkstra et al. 1990). In early broods, first-hatched chicks were predominantly males and last-hatched chicks were predominantly females; the opposite pattern appeared in late broods.

In several larid species late breeders are generally younger (Sydeman et al. 1991) or birds of poorer quality (Parsons 1975, Hunt and Hunt 1976, Brouwer et al. 1995). Data on the adults themselves are unfortunately not available for our study population. However, in this study lat- 
er breeders also laid significantly smaller eggs, supporting the idea that parents breeding later in the season are in poorer condition or younger, with different investment priorities. Because male-biased broods may be more demanding for the parents to rear, birds of poorer quality might bias their offspring sex ratio toward females, which agrees with our observations in second and third chicks late in the season. It remains unclear why the earliest breeders also tended to produce mainly female last-hatched chicks.

The functional significance of different offspring sex with hatching order is little understood. These combinations might differ in their nest success (Røskaft and Slagsvold 1985, Edwards et al. 1988, Bortolotti 1986, Bednarz and Hayden 1991, Nager et al. 2000, Badyaev et al. 2002, Velando et al. 2002, but see Drummond et al. 1991). The brood sex composition we found for parents that were presumably in poorer condition (breeding later in the season) showed the pattern that would be expected to be most successful under those conditions (Bradbury and Griffiths 1999). For facultative sex-ratio manipulation to be adaptive, it is important for females to predict food abundance for their chicks prior to egg laying (Dzus et al. 1996, Appleby et al. 1997, Sheldon 1998). In our study year, predictions of food supply made by the gulls at the start of breeding failed due to the establishment of a trawling moratorium once hatching started. Such stochastic events, which cause an unexpected decrease of food availability during chick rearing, may reduce breeding success even farther than when food availability is low throughout the whole breeding season. By tailoring the brood sex ratio to the anticipated poorer circumstances females might offset some of the negative effects on productivity. Further studies, including several years and, ideally, brood sex-ratio manipulation, are required to understand the functional significance of changes in offspring sex distribution with laying order through the breeding season.

\section{ACKNOWLEDGMENTS}

We are very grateful to Santi Mañosa and Albert Bertolero for their help in the fieldwork, to Lluís Jover and Roger Pradel for their statistical advice, to Kate Orr for her help in the laboratory, and to Albert Martínez and the staff of the Ebro Delta NP for their facilities. We also thank David S. Dobkin, Patricia Gowaty, Giacomo Tavecchia and an anonymous referee for comments and suggestions that improved the man- uscript. MG was supported by a grant of the Generalitat de Catalunya (CIRIT Project 1998BEAI200202).

\section{LITERATURE CITED}

Appleby, B. M., S. J. Petty, J. K. Blakey, P. Rainey, AND D. MacDonald. 1997. Does variation of sex ratio enhance reproductive success of offspring in Tawny Owls (Strix aluco)? Proceedings of the Royal Society of London Series B 264:11111116.

Badyaev, A. V., And G. E. Hill. 2000. The evolution of sexual dimorphism in the House Finch. Population divergence in morphological covariance structure. Evolution 54:1784-1794.

Badyaev, A. V., G. E. Hill, M. L. Beck, A. A. DerVAN, R. A. Duckworth, K. J. McGraw, P. M. Nolan, and L. A. Whittingham. 2002. Sex-biased hatching order and adaptive population divergence in a passerine bird. Science 295:316318.

Bednarz, J. C., AND T. J. HAyden. 1991. Skewed brood sex ratio and sex-biased hatching sequence in Harris's Hawks. American Naturalist 137:116132.

Bolton, M. 1991. Determinants of chick survival in the Lesser Black-backed Gull: relative contributions of egg size and parental quality. Journal of Animal Ecology 60:949-960.

Bortolotti, G. R. 1986. Influence of sibling competition on nestling sex ratios of sexually dimorphic birds. American Naturalist 127:495-507.

BRAdBURY, R. B., AND R. GRIFFITHS. 1999. Sex-biased mortality is influenced by hatching asynchrony in the Lesser Black-backed Gull. Journal of Avian Biology 30:316-322.

Brouwer, A., A. SpaAns, And A. A. N. DE Wit. 1995. Survival of Herring Gull Larus argentatus chicks: an experimental analysis of the need of early breeding. Ibis 137:272-278.

Burley, N. 1981. Mate choice by multiple criteria in a monogamous species. American Naturalist 117: 515-528.

Burnham, K. P., And D. R. Anderson. 1998. Model selection and inference, a practical informationtheoretic approach. Springer-Verlag, New York.

Burnham, K. P., D. R. Anderson, and G. C. White. 1994. Evaluation of the Kullback-Leibler discrepancy for model selection in open population capture-recapture models. Biometrical Journal 36: 299-315.

Burnham, K. P., D. R. Anderson, and G. C. White. 1995. Selection among open population capturerecapture models when capture probabilities are heterogenous. Journal of Applied Statistics 22: 611-624.

Clutton-Brock, T. H., S. D. Albon, and F. E. GuiNESS. 1985. Parental investment and sex differences in juvenile mortality in birds and mammals. Nature 313:131-133.

Cytel Software Corporation. 1990. EGRET version 2.0.3. Cytel Software Corporation, Cambridge, MA. 
DaAn, S., C. Dijkstra, and F. J. Weissing. 1996. An evolutionary explanation for seasonal trends in avian sex ratios. Behavioral Ecology 7:426-430.

Dijkstra, C., S. DaAn, AND J. B. BuKer. 1990. Adaptive seasonal variation in the sex-ratio of Kestrel broods. Functional Ecology 4:143-147.

Drummond, H., J. L. Osorno, R. Torres, C. GarciaChavelas, and H. M. Larios. 1991. Sexual size dimorphism and sibling competition: implications for avian sex ratios. American Naturalist 138:623641.

Dzus, E. H., G. R. Bortolotti, and J. M. Gerrard. 1996. Does sex-biased hatching order in Bald Eagles vary with food resources? Ecoscience 3:252258.

Edwards, T. C. JR., M. W. Collopy, K. Steenhof, And M. N. Kochert. 1988. Sex ratios of fledgling Golden Eagles. Auk 105:793-796.

Ellegren, H., L. Gustafsson, and B. C. Sheldon. 1996. Sex ratio adjustment in relation to parental attractiveness in a wild bird population. Proceedings of the National Academy of Sciences 93: $11723-11728$.

EMLEN, S. T. 1997. When mothers prefer daughters over sons. Trends in Ecology \& Evolution 12: 291-292.

FrANK, S. A. 1990. Sex allocation theory for birds and mammals. Annual Review of Ecology and Systematics 21:13-55.

Genovart, M., D. Oro, And F. Bonhomme. 2003. Genetic and morphological differentiation between the two largest breeding colonies of Audouin's Gull Larus audouinii. Ibis 145:448-456.

GowATY, P. A. 1991. Facultative manipulation of sex ratios in birds. Rare or rarely observed? Current Ornithology 8:141-171.

GRIFFITHS, R. 1992. Sex-biased mortality in the Lesser Black-backed Gull Larus fuscus during the nestling stage. Ibis 134:237-244.

Griffiths, R., S. DaAn, and C. Dijkstra. 1996. Sex identification in birds using two CHD genes. Proceedings of the Royal Society of London Series B 263:1251-1256.

Griffiths, R., M. C. Double, K. Orr, and R. J. G. DAwson. 1998. A DNA test to sex most birds. Molecular Ecology 7:1071-1076.

Griffiths, R., B. TIWARI, AND S. A. BECKER. 1992. The identification of sex in the Starling Sturnus vulgaris using a molecular technique. Molecular Ecology 1:191-194.

HéBert, P. N., AND R. M. R. Barclay. 1988. Parental investment in Herring Gulls: clutch apportionment and chick survival. Condor 90:332-338.

Hosmer, D. W., And S. Lemeshow. 1989. Applied logistic regression. Wiley Interscience, Chichester, UK.

Hunt, G. L., AND M. W. HunT. 1976. Gull chick survival: the significance of growth rates, timing of breeding and territory size. Ecology 57:62-75.

Kalmbach, E., R. G. NAGER, R. GRiffiths, and R. W. FURNESS. 2001. Increased reproductive effort results in male-biased offspring sex ratio: an experimental study in a species with reversed sexual dimorphism. Proceedings of the Royal Society of London Series B 268:2175-2179.

Krackow, S. 1995. Potential mechanisms for sex ratio adjustment in mammals and birds. Biological Review 70:225-241.

LACK, D. 1954. The natural regulation of animal numbers. Clarendon Press, Oxford, UK.

Leroux, A., And V. Bretagnolle. 1996. Sex ratio variations in broods of Montagu's Harriers Circus pygargus. Journal of Avian Biology 27:63-69.

Lessells, C. M., C. Mateman, AND J. Visser. 1996. Great Tit hatchling sex ratios. Journal of Avian Biology 27:135-142.

Meathrel, C. E., AND J. P. Ryder. 1987. Sex ratios of Ring-billed Gulls in relation to egg size, egg sequence and female body condition. Colonial Waterbirds 10:72-77.

Mock, D. W., AND G. A. Parker. 1997. The evolution of sibling rivalry. Oxford University Press, Oxford, UK.

Nager, R. G., P. Monaghan, R. Griffiths, D. C. Houston, AND R. DAwson. 1999. Experimental demonstration that offspring sex ratio varies with maternal condition. Proceedings of the National Academy of Sciences 96:570-573.

Nager, R., P. Monaghan, D. C. Houston, and M. Genovart. 2000. Parental condition, brood sex ratio and differential young survival: an experimental study in gulls (Larus fuscus). Behavioral Ecology and Sociobiology 48:452-457.

ORO, D. 1998. Audouin's Gull account, p. 47-61. In M. A. Ogilvie [ED.], The birds of the Western Paleartic. Oxford University Press, Oxford, UK.

ORO, D. 1999. Trawler discards: a threat or a resource for opportunistic seabirds? Proceedings of the International Ornithological Congress 22:717-730.

Oro, D., L. Jover, AND X. RuIz. 1996. Influence of trawling activity on the breeding ecology of a threatened seabird, Audouin's Gull Larus audouinii. Marine Ecology Progress Series 139:19-29.

Oro, D., R. Pradel, and J. D. Lebreton. 1999. The effects of nest predation and food availability on life history traits in Audouin's Gull. Oecologia 118:438-445.

PARSONS, J. 1975. Seasonal variation in the breeding success of the Herring Gull: an experimental approach to pre-fledging success. Journal of Animal Ecology 44:536-541.

Post, E., M. C. Forchhammer, N. C. Stenseth, and R. LANGVATN. 1999. Extrinsic modification of vertebrate sex ratios by climatic variation. American Naturalist 154:194-204.

RøSkaft, E., AND T. Slasgvold. 1985. Differential mortality of male and female offspring in experimentally manipulated broods of the Rook. Journal of Animal Ecology 54:261-266.

Ruiz, X., J. GonzÁlez-Solís, D. Oro, AND L. Jover. 1998. Body size variation in Audouin's Gulls $L a$ rus audouinii: a density-dependent effect? Ibis 140:431-438.

RydER, J. P. 1983. Sex ratio and egg sequence in Ringbilled Gulls. Auk 100:726-729.

Ryder, J. P., AND B. M. TermaAt. 1987. Secondary sex-ratios and egg sequence in Herring Gulls. Auk 104:526-528. 
Sambrook, J., E. F. Fritsch, and T. Maniatis. 1989. Molecular cloning. A laboratory manual. 2nd ed. Cold Spring Harbor Laboratory Press, New York. SAyce, J. R., AND G. L. HunT JR. 1987. Sex-ratios of prefledging Western Gulls. Auk 104:33-37.

Sheldon, B. C. 1998. Recent studies of avian sex ratios. Heredity 80:397-402.

StenNing, M. J. 1996. Hatching asynchrony, brood reduction and other rapidly reproducing hypotheses. Trends in Ecology \& Evolution 11:243-246.

Sydeman, W. J., J. F. Penniman, T. M. Penniman, P. Pyle, And D. G. Ainley. 1991. Breeding performance in the Western Gull: effects of parental age, timing of breeding and year in relation to food availability. Journal of Animal Ecology 60:135149.

Tella, J. L., J. A. Donázar, J. J. Negro, and F. HiRALDO. 1996. Seasonal and interannual variations in the sex-ratio of Lesser Kestrel Falco naumanni broods. Ibis 138:342-345.

Torres, R., AND H. DRUMmOND. 1999. Variably malebiased sex ratio in a marine bird with females larger than males. Oecologia 118:16-22.
Trivers, R. L., AND D. E. Willard. 1973. Natural selection of parental ability to vary the sex ratio of offspring. Science 179:90-92.

Velando, A., J. Graves, and J. E. Ortega-Ruano. 2002. Sex ratio in relation to timing of breeding and laying sequence in a dimorphic seabird. Ibis 144:9-16.

Verboven, N., M. KÄKelÄ, AND M. ORell. 2002. Absence of seasonal variation in Great Tit offspring sex ratios. Journal of Avian Biology 33:138-142.

Weatherhead, P. J. 1983. Secondary sex ratio adjustment in Red-winged Blackbirds (Agelaius phoeniceus). Behavioral Ecology and Sociobiology 12: 57-61.

Weatherhead, P. J., and K. L. Teather. 1991. Are skewed fledging sex ratios in sexually dimorphic birds adaptive? American Naturalist 138:11591172.

Whittingham, L. A., And P. O. Dunn. 2001. Survival of extrapair and within-pair young in Tree Swallows. Behavioral Ecology 12:496-500.

Wiebe, K. L., AND G. R. Bortolotti. 1992. Facultative sex ratio manipulation in American Kestrels. Behavioral Ecology and Sociobiology 30:379-386. 